\title{
Entrepreneurial Intentions Among University's Students In Malaysia
}

\author{
Raazi Ahmad \\ Sunway University Business School, Sunway University \\ No. 5 Jalan Universiti Bandar Sunway \\ Malaysia. \\ raazi.ahmad29@gmail.com
}

\author{
Shehnaz Tehseen \\ Lecturer, Department of Management, Sunway University \\ Business School, Sunway University, \\ No. 5 Jalan Universiti Bandar Sunway, \\ Malaysia. \\ shehnazt@sunway.edu.my
}

\author{
Farkad Mahli \\ Universiti Kuala Lumpur \\ Higher Colleges of Technology \\ Malaysia. \\ UAE \\ fmahli@hct.ac.ae
}

\author{
Umme Mobasharat UI Jannat \\ Research Associate \\ Inter-research, Dhaka, \\ Bangladesh \\ uddinmj@gmail.com
}

\author{
Zuhaib Hassan Qureshi \\ Universiti Kuala Lumpur \\ Universiti Kuala Lumpur Business School \\ Kuala Lumpur, Wilayah Perseketuan \\ Malaysia \\ zhqureshi3@gmail.com
}

\begin{abstract}
The issue of employability is rising year by year, and Malaysia is also taking it as a serious challenge. The Malaysian government has carried out various initiatives to address the issue of employability; conversely, one of them was successfully promoting the development of entrepreneurship by increasing entrepreneurial courses for instance. The intention was to increase the entrepreneurial intentions amongst university's students to create job opportunities for themselves which could lead to a boost for a developing nation's economy as well. However, the government's initiatives did not succeed as they were expected. The main reason for it ending as a flopped plan was due to failing to identify an individual's intentions. Therefore, the primary purpose of this research is to inspect the Malaysian universities student's intention of being an entrepreneur because, without intention, they might not even consider the option of initiating their own business. This research adapted and integrated the two most common models of examining the entrepreneurial intention, i.e, Theory of Planned Behaviour ('TPB') by Ajzen and Shapero and Sokol's model of an Entrepreneurial Event ('SEE'). This is a quantitative study and a total of 160 students from different Malaysian universities
\end{abstract}

were surveyed using non-probability sampling techniques and by a well-established instrument with the standardized questionnaire, to examine hypothesized relationships. SPSS was used for analyzing the demographic profile and SMART-PLS was utilized for testing the developed hypotheses. The results show that attitude, subjective norms, and perceived behavioural control positively affect the perceived desirability as well as perceived feasibility. Moreover, perceived desirability and perceived feasibility are also positively associated with an entrepreneurial intention. Furthermore, perceived desirability is found as a mediator for the relationship among predictors of entrepreneurial intention but perceived feasibility fails to mediate the association of subjective norm and entrepreneurial intention. By understanding the background of university student's intentions towards entrepreneurship, the Malaysian government and organizations can better present themselves in formulating better initiatives to stimulate and encourage youth to have entrepreneurial intentions in order to initiate their own business. This study also offers some useful managerial implications using the advanced technique of IPM to enhance the 
performance of critical factors that contribute towards entrepreneurial intentions.

Keywords- Model of an Entrepreneurial Event, Theory of Planned Behaviour, Entrepreneurial Intentions, Malaysian universities'Students, PLS-SEM.

\section{INTRODUCTION}

Entrepreneurial intention contributes significantly in developing the entrepreneurial behaviors among individuals [32]. Therefore, it is essential to understand the development of entrepreneurial intention [23]. Although the Malaysian government has taken various support and incentive measures to attract entrepreneurial activities, unfortunately, it has not reached the level where the entrepreneurial activity becomes active. In spite of the enhancement of entrepreneur support measures, Malaysian's entrepreneurial activity is staying at a low level compared to developed countries as GEM stated that Malaysia has only $4.9 \%$ entrepreneurial intention which ranked on 64 out of 65 countries [7]. In the context of Malaysia according to [18], there are more than 30 private universities and around 20 university-colleges [20]. The Ministry of Education Malaysia has launched the policy regarding the Higher Education Entrepreneurship Development and following this policy, the entrepreneurship development's strategic plan in higher education (2013-2015) has been launched to enhance the implementation of entrepreneurial education [25].

Despite the efforts and initiatives of Malaysian higher educational institutions and Malaysian government regarding the entrepreneurship education, the Malaysian graduates show low interest in start-ups [25]. According to a Graduate Tracer Study by Ministry of Higher Education Malaysia in 2014, only $2 \%$ Malaysian graduates participated in new ventures after the six months of their graduation [25]. However, this percentage is less favourable considering the government's efforts to promote entrepreneurship among Malaysian graduates. Although a number of studies have been conducted regarding the entrepreneurial intentions among university students under various contexts [28], however, no study has been conducted among Malaysian students to determine their entrepreneurial intentions by integrating the Theory of Planned Behaviour ('TPB') and Model of Entrepreneurial Event ('SEE') theories. Based on our best knowledge, a general integration of SEE and TPB has not yet been studied in existing entrepreneurship studies. To fill this research gap, this study has utilized SEE to provide a deep insight regarding this issue. Particularly, this study has attempted to shed light that how attitudes, perceived norms, and perceived behavioural control impact perceived desirability, thus impacting the individuals' intention to act entrepreneurially. Thus, the present study has two key objectives:
1. To investigate the impacts of attitude, perceived behavioural control and subjective norms on perceived feasibility and perceived desirability.

2. To investigate the impacts of perceived desirability and perceived feasibility on entrepreneurial intentions.

3. To investigate the mediating impacts of perceived desirability and perceived feasibility in the relationship among attitude, subjective norms, and perceived behavioural control and entrepreneurial intention.

In short, this study has addressed the call to integrate the related theories with entrepreneurial intention models along with advanced methodology [6]. This study makes two key contributions. Firstly, theoretically it integrates TPB and SEE in single comprehensive model to improve the understanding regarding entrepreneurial intention. It has supported the TPB's applicability and the concept that intention can be only better predicted through its closely related attitudinal factors constituting the attitude, social norms, and perceived behavioural control [2]. In addition, integration of both theories better explains the motivational process towards entrepreneurial intention [9]. Secondly, this study contributes methodologically as well by employing an advanced approach using PLS-SEM technique to test the study's hypotheses as well as to validate the model among male and female universities' students.

\section{DEVELOPMENT OF THEORETICAL FRAMEWORK}

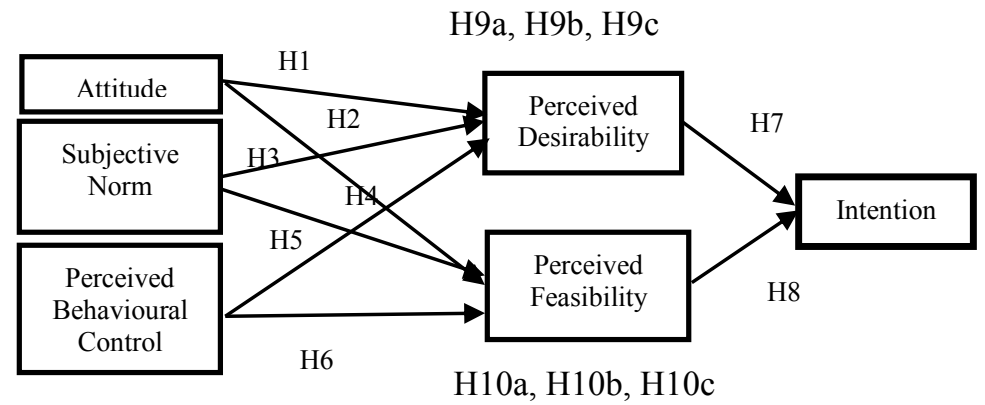

Figure 3: Theoretical Framework

\section{A. Development of Hypotheses}

1) The Influence of University Student's Attidue on Perceived Desirability.

Attitude for an act indicates how positively or negatively attractive the behaviour, such as entrepreneurship, is to an individual [1]. The universal degree of attitude towards entrepreneurial behavior imitates individuals' beliefs of how overall desirable or undesirable its outcomes are [30]. The intention of carrying out the particular behaviour is dependent on their attitude to the behaviour [1]. Attitude, in turn, is based on the individual's appraisal of initiating an entrepreneurial effort [16]. Hence, the initial reason that an individual give to take up entrepreneurship provides researchers with a thoughtful insight into whether the subject will engage 
positively in entrepreneurial activity as was their intention [29]. These mould their assessment of entrepreneurship, their attitudes and desirability towards becoming an entrepreneur [8]. Therefore, the following hypothesis is established:

H1: The university students' attitudes positively influence their perceived desirability.

\section{2) The Influence of University Students' Attitude on Perceived Feasibilty}

As mentioned by [1], the attitude of an individual towards any certain behaviour is the extent to which he/she is either negative or positive after considering the behaviour. And since the perceived feasibility is the degree to which the persons believe that they have the essential resources to successfully complete a task [26]. Thus, based on the above statements, the subsequent hypothesis can be established:

H2: The university students' attitudes positively influence their perceived feasibility.

\section{3) The Influence of University Students' Subjective Norm} on Perceived Desirability.

To determine the perceived social pressure from partners, relatives, and other social members such as friends, subjective norms are used by looking into people's perceptions of certain behaviours [1]. Perceived desirability is how certain thing attracts individual behaviour and defers from person to person based on their own preferences. Thus, the perceived desirability of entrepreneurship can be lowered if subjective norms disapprove of the pursuit, thus deterring the student from entrepreneurship. Thus, the relevant hypothesis is as follow:

H3: The university students' subjective norms positively influence their perceived desirability.

\section{4) The Influence of University Students' Subjective Norm on Perceived Feasibilty}

Subjective norms indicate the perceived social pressures to follow or not follow the specific behaviour [1]. Namely, they refer to an opinion of other people regarding proposed behaviour. Whereas, perceived feasibility as mentioned earlier, is the extent of an individuals' belief that they have the required resources to successfully accomplish a task [26] and is the ability to carry out certain behaviour [17]. Since in the current business environments, various cultural, technological, social, economic as well as political factors impact on the perceived feasibility of individuals regarding their entrepreneurial intentions and other opinions may also impact on individuals' perceived feasibility in this regard [8]. Thus, based on the above arguments, this study hypothesizes the positive influence of both variables as follow:

H4: The university students' subjective norms positively influence their perceived feasibility.

\section{5) The Influence of University Students' Perceived Behavioural Control on Perceived Desirability}

According to [11], perceived behavioural control can motivate or demotivate an individual based on the behaviour required to achieve the action. If entrepreneurship requires behaviours that are considered too difficult, the perceived desirability may be lowered. Perceived behavioural control indicates the situational competence's perception and shows the perceived ability to be self-employed. [8] viewed the perceived behavioural control as self-efficacy that reflects the feasibility and can be affected by various obstacles. As an alternative, the perceived desirability is also relevant to beliefs. Moreover, a statistically positive correlation was discovered between entrepreneurial belief and entrepreneurial intention [14]. Thus, the following hypothesis can be developed in this regard:

H5: The university students' perceived behavioural controls positively influence their perceived desirability.

\section{6) The Influence of University Students' Perceived Behavioural Control on Perceived Feasibility}

Perceived feasibility can be delineated as the extent to which individuals on a personal level regard themselves capable of carrying out a particular behaviour. Role models, partners, and mentors help an individual conclude whether the individual has sufficient levels of entrepreneurial ability [4]. In addition, [3] stated that perceived behavioural control has also corresponded with perceived feasibility as well. The following hypothesis is developed in this regard:

H6: The university students' perceived behavioural controls positively influence their perceived feasibility.

\section{7) The Influence of University Student's Perceived Desirability on Entrepreneurial Intention}

Entrepreneurial Intention is one of the crucial fundamentals that contributes to the development and progress of entrepreneurship, raises independence and leads to creativities [27]. Likewise, many studies have demonstrated perceived desirability as a major indicator of student's intentions at transitioning into entrepreneurship. Based on the empirical studies conducted by [15] perceived desirability is confirmed as the most important of the factors that affect entrepreneurial intentions. Desirability is also related to beliefs 
and [14] advocated the statistical positive impact of entrepreneurial belief on entrepreneurial intention of someone running their own business. Either way, perceived desirability is proposed by these researchers to be a key factor in entrepreneurial intent. [3] concluded the same, confirming the hypothesis. Thus, the related hypothesis is established as follow:

H7: The university students' perceived desirability positively influences their intention to become an entrepreneur.

\section{8) The Influence of University Student's Perceived Feasibilty on Entrepreneurial Intention}

Many studies have hypothesized the positive relationship between student's perceived feasibility and entrepreneurial intention under various contexts [4]. The perceived feasibility is one of the most significant factors in SEE model which manipulate decision making of starting a new business or venture. The perceived feasibility is a degree of which people positively think that they have the capability to be a successful business's person [26]. Likewise, some other studies have also tested the influence of perceived feasibility on entrepreneurship intentions. It was concluded that perceived feasibility is a major factor on entrepreneurial intentions, by boosting it positively among international students in their final year at UMS, based on the results that showed most of the students considered themselves capable of becoming entrepreneurs [17]. Hence, based on the aforementioned arguments, the following hypothesis is formulated.

H8: The university students' perceived feasibility positively influences their intention to become entrepreneurs.

\section{9) Mediating Effects of perceived desirability and perceived feasibility}

Mediating effects of perceived desirability and perceived feasibility based on above literature, since studies have found the positive influence of attitude on perceived desirability, subjective norms and perceived desirability, perceived behavioural control and perceived desirability; and also, on attitude \& perceived feasibility, subjective norms and perceived feasibility, and perceived behavioural control and perceived feasibility [22]. Likewise, [5] has also found positive mediating role of perceived desirability between entrepreneur's characteristics and entrepreneurial intentions. Thus, perceived desirability and perceived feasibility could act as mediators between the relationships of independent variables (attitude, subject norms, perceived behavioural control) and dependent variable (intention) based on existing studies [4]. Thus, the following hypotheses are established:
H9a There is a mediating effect of perceived desirability for the influence of attitude on entrepreneurial intention.

$\mathrm{H} 9 \mathrm{~b}$ There is a mediating effect of perceived desirability for the influence of subjective norms on entrepreneurial intention.

H9c There is a mediating effect of perceived desirability for the influence of perceived behaviour control on entrepreneurial intention.

H1Oa There is a mediating effect of perceived feasibility for the influence of attitude on entrepreneurial intention.

$\mathrm{H} 10 \mathrm{~b}$ There is a mediating effect of perceived feasibility for the influence of subjective norms on entrepreneurial intention.

H1Oc There is a mediating effect of perceived feasibility for the influence of perceived behaviour control on entrepreneurial intention.

\section{METHODOLOGY}

It was a quantitative study which employed survey method to collect data from 160 undergraduate students of Malaysian universities from Selangor and Kuala Lumpur. Data were collected in cross sectional setting and data were obtained through techniques of non-random sampling. Standard instrument was used to measure all constructs. All the items used the five-point Likert scales to measure responses. "Entrepreneurial Intention" was the dependent variable measured with 5 items that were adopted from [17]. "Personal Attitude towards Self-Employment" was the independent variable measured with 3 items adopted from [13]. On the other hand, the other independent variables namely Subjective Norm and Perceived Behavioural Control, each measured with 3 items were adopted from [19] the mediator variables namely Perceived Desirability measured with 5 items and Perceived Feasibility measured with 6 items were adopted from [17].

\section{A. Data Analysis}

\section{1) Descriptive Data Analysis and Inferential Data} Analysis

The demographic profiles of respondents were assessed by using SPSS. Whereas, PLS-SEM technique was used to test hypotheses by using SMART-PLS software.

\section{ANALYSIS AND RESUltS}

\section{A. Descriptive Statistic}

160 questionnaires were distributed to subjected respondents in Malaysia universities. Majority of respondent's age (93.1\%) were between 21 to 23 years old. More than half respondents were females (64.4\%). Most of the respondent's race were occupying by Chinese $(60 \%)$ and following second highest was Malay (26.3\%). 43.8\% of respondents were having qualified certificate as their highest education and $36.9 \%$ respondents were having 
high school qualification. The majority of respondents belonged to a middle-class family background (68.8\%), half of the respondent's family owned business $(49.4 \%)$ and another half were not $(50.6 \%)$.

\section{B. Results of Inferential Analysis using PLS-SEM}

\section{1) Measurement Model Assessment}

The composite reliability (CR), Cronbach's alpha, rho A, and Average Variance Extracted (AVE) were assessed in measurement model analysis (Ramayah et al., 2018; Hair et al. 2017). The outcome of rho A for this research reported ranged between 0.838 to 0.940 which shows sufficient reliability for all the variables.

Next, as Hair et al. (2017) suggested for items that values of outer loadings are acceptable to examine when ranged is between 0.4 to 0.7 can be retained if they do lower the values of $\mathrm{CR}$ and AVE of any construct otherwise those items should be eliminated from examination. We found that all the items have values above 0.7 which is sufficiently meet the thresholds shown in Table 1.

TABLE 1

SCORES OF RELIABILITIES AND CONVERGENT VALIDITY

\begin{tabular}{|c|c|c|c|c|c|c|}
\hline Constructs & Items & $\begin{array}{c}\text { Outer } \\
\text { Loadings }\end{array}$ & $\begin{array}{c}\text { Cronbach's } \\
\text { Alpha }\end{array}$ & rho_A & $\begin{array}{l}\text { Composite } \\
\text { Reliability } \\
\text { (CR) }\end{array}$ & $\begin{array}{c}\text { Average } \\
\text { Variance } \\
\text { Extracted } \\
\text { (AVE) }\end{array}$ \\
\hline \multirow[t]{3}{*}{ ATT } & ATT1 & 0.913 & \multirow[t]{3}{*}{0.875} & \multirow[t]{3}{*}{0.875} & \multirow[t]{3}{*}{0.923} & \multirow[t]{3}{*}{0.801} \\
\hline & ATT2 & 0.910 & & & & \\
\hline & ATT3 & $\begin{array}{l}0.861 \\
\end{array}$ & & & & \\
\hline \multirow[t]{5}{*}{ EI } & EI1 & 0.847 & \multirow[t]{5}{*}{0.938} & \multirow[t]{5}{*}{0.940} & \multirow[t]{5}{*}{0.953} & \multirow[t]{5}{*}{0.802} \\
\hline & EI2 & 0.933 & & & & \\
\hline & EI3 & 0.872 & & & & \\
\hline & EI4 & 0.920 & & & & \\
\hline & EI5 & 0.903 & & & & \\
\hline \multirow[t]{3}{*}{ PBC } & PBC1 & 0.887 & \multirow[t]{3}{*}{0.875} & \multirow[t]{3}{*}{0.877} & \multirow[t]{3}{*}{0.923} & \multirow[t]{3}{*}{0.80} \\
\hline & $\begin{array}{l}\text { PBC2 } \\
\end{array}$ & 0.920 & & & & \\
\hline & PBC3 & 0.875 & & & & \\
\hline \multirow[t]{5}{*}{ PD } & PD1 & 0.804 & \multirow[t]{5}{*}{0.897} & \multirow[t]{5}{*}{0.905} & \multirow[t]{5}{*}{0.924} & \multirow[t]{5}{*}{0.711} \\
\hline & PD2 & 0.865 & & & & \\
\hline & PD3 & 0.769 & & & & \\
\hline & PD4 & 0.870 & & & & \\
\hline & PD5 & 0.900 & & & & \\
\hline \multirow[t]{6}{*}{ PF } & PF1 & 0.817 & \multirow[t]{6}{*}{0.894} & \multirow[t]{6}{*}{0.896} & \multirow[t]{6}{*}{0.919} & \multirow[t]{6}{*}{0.654} \\
\hline & PF2 & 0.809 & & & & \\
\hline & PF3 & 0.769 & & & & \\
\hline & PF4 & 0.792 & & & & \\
\hline & PF5 & 0.816 & & & & \\
\hline & PF6 & 0.848 & & & & \\
\hline \multirow[t]{3}{*}{ SNN } & SNN1 & 0.862 & \multirow[t]{3}{*}{0.836} & \multirow[t]{3}{*}{0.838} & \multirow[t]{3}{*}{0.902} & \multirow[t]{3}{*}{0.753} \\
\hline & $\begin{array}{l}\text { SNN2 } \\
\end{array}$ & 0.872 & & & & \\
\hline & SNN3 & 0.871 & & & & \\
\hline
\end{tabular}

Moreover, the discriminant validity of the constructs was also assessed by using HTMT criterion. Table 2 reveals that the sufficient discriminant validity as threshold values are below 0.9 [12].
TABLE 2

HETEROTRAIT-MONOTRAIT RATIO (HTMT)

\begin{tabular}{|c|c|c|c|c|c|c|}
\hline Constructs & ATT & EI & PBC & PD & PF & SNN \\
\hline ATT & & & & & & \\
\hline EI & 0.77 & & & & & \\
\hline PBC & 0.632 & 0.594 & & & & \\
\hline PD & 0.866 & 0.858 & 0.639 & & & \\
\hline PF & 0.697 & 0.685 & 0.887 & 0.716 & & \\
\hline SNN & 0.572 & 0.5 & 0.614 & 0.684 & 0.618 & \\
\hline
\end{tabular}

\section{2) Structure Model Assessment}

The assessment of the structural model constitutes the analysis of collinearity assessment, testing of relationships, and assessment of $\mathrm{R}^{2}, \mathrm{f}^{2}$, and $\mathrm{Q}^{2}$ values as suggested by [10]. There is no multicollinearity in this model as all item's VIF values are lower than 5 . The hypotheses testing was done by using Bootstrapping procedure. Table 3 summarized the all the direct relationships of hypothesis (H1 to H8) and Table 4 summarised indirect effects (medication analysis: H9a to H10c). Hypothesis is supported when the $\mathrm{T}$ values reports greater than 1.64 (significant level $=10 \%$ ), Table 3 reports that ATT, SNN and PBC significantly influence the perceived desirability since the t-statistics value is $10.963,3.793$ and 1.958 respectively. Therefore, H1, H3, and $\mathrm{H} 5$ are supported. Also, attitude $(\mathrm{t}$-stats $=4.234)$, subjective norm $(\mathrm{t}$-stats $=$ 1.728) and perceived behavioural control (t-stats $=11.271)$ significantly influence perceived feasibility. Hence, H2, H4, and H6 are supported. Moreover, PD and PF have a significant influence on entrepreneurial intention since the t-statistics value is 12.33 and 3.331 respectively. Therefore, $\mathrm{H} 7$ and $\mathrm{H} 8$ are supported.

TABLE 3

HYPOTHESIS TESTING OF DIRECT EFFECTS (H1, H2, H3, H4, H5, H6, $\mathrm{H} 7, \mathrm{H} 8)$

\begin{tabular}{|c|c|c|c|c|c|c|c|}
\hline Hypotheses & Relationships & $\begin{array}{l}\text { Original } \\
\text { Sample } \\
\text { (O) }\end{array}$ & $\begin{array}{l}\text { Sample } \\
\text { Mean } \\
\text { (M) }\end{array}$ & $\begin{array}{l}\text { Standard } \\
\text { Deviation } \\
\text { (STDEV) } \\
\end{array}$ & $\begin{array}{c}\text { T Statistics } \\
\text { (|O/STDEV|) }\end{array}$ & $\begin{array}{c}\mathbf{P} \\
\text { Values }\end{array}$ & Decision \\
\hline H1 & ATT $->$ PD & 0.589 & 0.584 & 0.054 & ***10.963 & 0 & Supported \\
\hline H2 & ATT $>$ PF & 0.236 & 0.235 & 0.056 & $* * * 4.234$ & 0 & Supported \\
\hline H3 & SNN $->$ PD & 0.242 & 0.244 & 0.064 & $* * * 3.793$ & 0 & Supported \\
\hline H4 & SNN $>>$ PF & 0.102 & 0.101 & 0.059 & $" 1.728$ & 0.085 & Supported \\
\hline H5 & $\mathrm{PBC}->\mathrm{PD}$ & 0.118 & 0.123 & 0.06 & *1.958 & 0.051 & Supported \\
\hline H6 & $\mathrm{PBC}->\mathrm{PF}$ & 0.604 & 0.606 & 0.054 & $* * * 11.271$ & 0 & Supported \\
\hline H7 & PD $>$ EI & 0.662 & 0.663 & 0.054 & $* * * 12.33$ & 0 & Supported \\
\hline H8 & PF $>$ EI & 0.2 & 0.2 & 0.06 & $* * 3.331$ & 0.001 & Supported \\
\hline
\end{tabular}

Note: ${ }^{*}$ Critical t values ${ }^{*} 1.645$ (significant level $\left.=10 \%\right) ; * * 1.96$ (significant level $\left.=5 \%\right) ;$ and $* * * 2.57$ (significant level $=1 \%$ )

The result of bootstrapping has shown that the four indirect effects, $\beta=0.39, \beta=0.16, \beta=0.078, \beta=0.047, \beta=0.121$, are significant with t-values of $7.098,3.764,1.939,2.453$, and 3.139 respectively. Only the testing of H13 shows nonsignificant $\mathrm{t}-$ value of which $\beta$ is 0.02 . Moreover, for $\mathrm{H} 9, \mathrm{H} 10$, $\mathrm{H} 11, \mathrm{H} 12$, and H14, the indirect effects 95\% Boot CL Bias Corrected: $[\mathrm{LL}=0.287,0.498], \quad[\mathrm{LL}=0.079,0.236], \quad[$ $\mathrm{LL}=0.006,0.164]$, $[\mathrm{LL}=0.019,0.1]$, and $[\mathrm{LL}=0.048,0.197]$ do not overlap a 0 in between indicating there is mediation 
(Preacher \& Hayes, 2004, 2008). Therefore, we can conclude that the mediation effects are statistically significant as shown in Table 4.

TABLE 4

HYPOTHESIS TESTING OF INDIRECT EFFECTS (MEDIATION: H9A, H9B, H9C, H10A, H10B, H10C)

\begin{tabular}{|c|c|c|c|c|c|c|c|}
\hline Hypotheses & Relationships & $\begin{array}{l}\text { Original } \\
\text { Sample } \\
\text { (O) }\end{array}$ & $\begin{array}{l}\text { Sample } \\
\text { Mean } \\
\text { (M) }\end{array}$ & $\begin{array}{l}\text { Standard } \\
\text { Deviation } \\
\text { (STDEV) }\end{array}$ & $\begin{array}{c}\text { T Statistics } \\
(\mid \mathbf{O} / \text { STDEV } \mid)\end{array}$ & $\begin{array}{c}P \\
\text { Values }\end{array}$ & Decision \\
\hline H9a & $\begin{array}{c}\text { ATT }>\text { PD }>> \\
\text { EI }\end{array}$ & 0.39 & 0.389 & 0.055 & $* * * 7.098$ & 0 & Supported \\
\hline H9b & $\begin{array}{c}\text { SNN }>>\text { PD - } \\
>\text { EI }\end{array}$ & 0.16 & 0.161 & 0.043 & $* * 3.764$ & 0 & Supported \\
\hline H9c & $\begin{array}{c}\mathrm{PBC}->\mathrm{PD}>> \\
\mathrm{EI}\end{array}$ & 0.078 & 0.082 & 0.04 & *1.939 & 0.053 & Supported \\
\hline H10a & $\begin{array}{c}\text { ATT }->\text { PF }-> \\
\text { EI }\end{array}$ & 0.047 & 0.047 & 0.019 & $* * 2.453$ & 0.015 & Supported \\
\hline H10b & $\begin{array}{c}\mathrm{SNN}->\mathrm{PF}-> \\
\text { EI }\end{array}$ & 0.02 & 0.02 & 0.013 & 1.63 & 0.104 & $\begin{array}{c}\text { Not } \\
\text { supported }\end{array}$ \\
\hline H10c & $\begin{array}{c}\mathrm{PBC}>\mathrm{PF}>> \\
\mathrm{EI}\end{array}$ & 0.121 & 0.121 & 0.038 & $* * * 3.139$ & 0.002 & Supported \\
\hline
\end{tabular}

Note: $*$ Critical $\mathrm{t}$ values $* 1.645($ significant level $=10 \%) ; * 1.96($ significant level $=5 \%)$; and $* * 2.57$ (significant level $=1 \%$.

Moreover, the $\mathrm{R}^{2}$ value - the coefficient of determination was also assessed for each of the dependent variable. The $\mathrm{R}^{2}$ values of EI and PD were 0.650 and 0.666 respectively. On the other hand, $\mathrm{R}^{2}$ value of $\mathrm{PF}$ was $0.676 . \mathrm{f}^{2}$ is also needed to be assessed to identify the substantial impact of a specific exogenous construct on the particular endogenous latent variable. $\mathrm{f}^{2}$ values of $\mathrm{ATT}$ for $\mathrm{PD}$ and $\mathrm{PF}$ were 0.664 and 0.110 respectively. Likewise, $\mathrm{f}^{2}$ values of $\mathrm{PBC}$ for $\mathrm{PD}$ and $\mathrm{PF}$ were 0.025 and 0.685 respectively. $\mathrm{f}^{2}$ values of $\mathrm{PD}$ and $\mathrm{PF}$ for EI were 0.727 and 0.066 . Furthermore, $\mathrm{f}^{2}$ values of SNN for $\mathrm{PD}$ and $\mathrm{PF}$ were 0.117 and 0.021 respectively. The $\mathrm{Q}^{2}$ values were also assessed to evaluate the predictive relevance of the model. The $\mathrm{Q}^{2}$ value of more than 0 indicates predictive relevance for the specific reflective endogenous construct [21]. The $\mathrm{Q}^{2}$ values of EI. PD, and PF are $0.487,0.438$, and 0.409 respectively which reveal sufficient predictive relevance for the specific reflective endogenous constructs.

\section{DISCUSSION}

The results of $\mathrm{H} 1$ revealed positive association of attitude with perceived desirability, and $\mathrm{H} 2$ finding showed positive relationship of attitude with perceived feasibility. These results are in line with other studies that also found same relationship among students [22; 24]. Likewise, the findings of $\mathrm{H} 3$ and $\mathrm{H} 4$ regarding positive relationship between subjective ${ }^{[}$ norm and perceived desirability as well as between subjective norm and perceived feasibility are consistent with some other studies as well $[31 ; 13]$. Similarly, results of $\mathrm{H} 5$ and $\mathrm{H} 6$ regarding positive relationship of perceived behavioural control with perceived desirability and positive relationship of perceived behavioural control and perceived feasibility are also in line with other studies that also found similar relationships in different contexts $[31 ; 24 ; 13]$. Moreover, the results of $\mathrm{H} 7$ and $\mathrm{H} 8$ found positive relationship between perceived desirability and entrepreneurial intention as well as[18] between perceived desirability and entrepreneurial intention that are also consistent with some other studies as well [13].
On the other hand, the results of H9a, H9b, H9c as well as $\mathrm{H} 10 \mathrm{a}$ and $\mathrm{H} 10 \mathrm{c}$ which found positive mediating impacts of perceived desirability and perceived feasibility among independent variables and entrepreneurial intention, is very new contribution of study since no significant existing study has assessed the mediating impacts.

\section{REFERENCES}

[[1] Ajzen, I., "The theory of planned behavior", Organizational Behavior and Human Decision Processes, vol.50, no.2, pp.179-211, 1991.

[2] Ajzen, I., "The theory of planned behaviour: Reactions and reflections", Psychology \& Health, vol.26, no.9, pp.1113-1127, 2011.

[3[3] Autio, E., Keeley, R. H., Klofsten, M., Parker, G. G. C., and Hay, M., "Entrepreneurial intent among students in Scandinavia and in the USA", Enterprise and Innovation Management Studies, vol.2, no.2, pp.45-160, 2001.

[4[4] Dissanayake, D. M. N. S. W. "The impact of perceived desirability and perceived feasibility on entrepreneurial intention among undergraduate students in Sri Lanka: An extended Model", The Kelaniya Journal of Management, vol.2, no.1, pp.39-57, 2013.

[5[5] Eid, R., Badewi, A., Selim, H., and El-Gohary, H., "Integrating and extending competing intention models to understand the entrepreneurial intention of senior university students. Education+ Training, vol.61, no.2, pp.234-254, 2019.

6[6] Fayolle, A., Liñán, F., and Moriano, J. a., "Beyond entrepreneurial intentions: values and motivations in entrepreneurship", International Entrepreneurship and Management Journal, vol.10, no.4, pp.679-689, 2014

[[[7] GEM.,"GEM Global entrepreneurship monitor global report 2016/17”, 2017. [Online]. Available: https://www.gemconsortium.org/report/49812.

[ [8] Giagtzi, Z., "How perceived feasibility and desirability of entrepreneurship influence entrepreneurial intentions", 2013. [Online]. Available: http://hdl.handle.net/2105/13598.

[9] Hagger, M. S., and Chatzisarantis, N. L., "Integrating the theory of planned behaviour and self-determination theory in health behaviour: A meta-analysis", British journal of health psychology, vol.14, no.2, pp.275-302, 2009 .

[[10] Hair, J. F., Hult, G. T. M., Ringle, C. M. and Sarstedt, M., "A Primer on Partial Least Squares Structural Equation Modeling (PLS-SEM)", $2^{\text {nd }}$ ed., Thousand Oaks, CA: Sage, 2017.

[1[[11] Hardin-Fanning, F., and Ricks, J. M., "Attitudes, social norms and perceived behavioral control factors influencing participation in a cooking skills program in rural Central Appalachia", Global health promotion, vol.24, no.4, pp.43-52, 2017.

1[[12] Henseler, J., Ringle, C. M., and Sarstedt, M., "A new criterion for assessing discriminant validity in variance-based structural equation modeling", Journal of the academy of marketing science, vol.43, no.1, pp.115-135, 2015 .

[13] Iakovleva, T., and Kolvereid, L., "An integrated model of entrepreneuria intentions", International Journal of Business and Globalisation, vol.3, no.1, pp.66, 2009, doi:10.1504/ijbg.2009.021632

[14] Kumara, S., "Undergraduates intention towards entrepreneurship: Empirica evidence from Sri Lanka", Journal of Enterprising Culture, vol.20, no.01, pp.105-118, 2012.

15] Linan, F., Rodriguez-Cohard, J., and Rueda-Cantuche, J., "Factors affecting entrepreneurial intention levels:a role for education", International Entrepreneurship and Management Journal, vol.7, no.2, pp.195-218, 2011

6] Malebana, M., "The effect of knowledge of entrepreneurial support on entrepreneurial intention", Mediterranean Journal of Social Sciences, 2014.

7] Masury, M., "The impact of perceived feasibility and perceived desirability on entrepreneurialintention among undergraduate students in Universitas Muhammadiyah", 2016. [Online]. Available: http://eprints.ums.ac.id/47996/6 /MUKHAMMAD\%20JAUHAR\%20uploaaad.pdf

Ministry of Higher Education,

(2013) 
[19] Misoska, A.T, Dimitrova, M., and Mrsik, J., "Drivers of entrepreneurial intentions among business students in Macedonia", Economic researchEkonomska istraživanja, vol.29, no.1, pp.1062-1074, 2016.

[20] Qureshi, Z. H., Al Halbusi, H., Pitafi, S., Tehseen, S., “A Conceptual Study of HRM Practices and Market Orientation on Lecturer's Retention: A Case Study of Malaysian Universities", Business Ethics and Leadership, vol.2, no.3, pp.44-52, 2018. DOI: 10.21272/bel.2(3).44-52.2018.

[21] Ramayah, T., Cheah, J., Chuah, F., Ting, H., Memon, M.A., "Partial Least Squares Structural Equation Modelling (PLS-SEM) using SMARTPLS 3.0: An Updated and Practical Guide to Statistical Analysis", 2nd edt., Pearson: Malaysia, 2018.

[22] Riquelme, H., and Lanqawi, A. "The Desire that Propels Entrepreneurial Intentions", Journal of Entrepreneurship, Management and Innovation, vol.12, no.2, pp.123-150, 2016.

[23] Saraih, U. N., Aris, A. Z. Z., Mutalib, S. A., Ahmad, T. S. T., and Amlus, M. H., "Examining The Relationships between Attitude Towards Behaviour, Subjective Norms and Entrepreneurial Intention among Engineering Students", In MATEC Web of Conferences, vol. 150, p. 05011, EDP Sciences, 2018.

[24] Schlaegel, C., and Koenig, M., "Determinants of entrepreneurial intent: a meta-analytic test and integration of competing models", Entrepreneurship Theory and Practice, vol.38, no.2, pp.291-332, 2014.

[25] Shamsudin, S. F. F. B., Al Mamun, A., Nawi, N. B. C., Nasir, N. A. B. M., and Zakaria, M. N. B., "Factors Affecting Entrepreneurial Intention Among the Malaysian University Students", The Journal of Developing Areas, vol.51, no.4, pp.423-431, 2017.

[26] Shapero, A., and Sokol, L., "Social Dimensions of Entrepreneurship", Kent, C.A.; Sexton, D. L. and Vesper, K. H., eds, Encyclopedia of Entrepreneurship, Prentice Hall, Englewood Cliffs (NJ), pp.72-90, 1982.

[27] Sharaf, A., El-Gharbawy, A., and Ragheb, M. A., "Factors That Influence Entrepreneurial Intention within University Students in Egypt", Open Access Library Journal, vol.5, no.10, pp.1, 2018.

[28] Sun, H., Lo, C. T., Liang, B., and Wong, Y. L. B., "The impact of entrepreneurial education on entrepreneurial intention of engineering students in Hong Kong”, Management Decision, vol.55, no.7, pp.1371-1393, 2017.

[29] Tran, A., and Von Korflesch, H., "A conceptual model of social entrepreneurial intention based on the social cognitive career theory", Asia Pacific Journal of Innovation and Entrepreneurship, vol.10, no.1, pp.17-38, 2016.

[30] Usman, B., "Understanding the entrepreneurial intention among international students in Turkey", Journal of Global Entrepreneurship Research, vol.9, no. 1, pp.10, 2019.

[31] Utami, C., "Attitude, Subjective Norms, Perceived Behaviour, Entrepreneurship Education and Self efficacy toward Entrepreneurial Intention University Student Indonesia", European Research Studies Journal, vol.2A, pp.475-495, 2017.

[32] Zaremohzzabieh, Z., Ahrari, S., Krauss, S. E., Samah, A. B. A., Meng, L. K., and Ariffin, Z., "Predicting social entrepreneurial intention: A meta-analytic path analysis based on the theory of planned behavior", Journal of Business Research, vol.96, pp.264-276, 2019. 